\title{
PRELIMINARY INVESTIGATION OF THE LAND SUBSIDENCE PHENOMENA OCCURRING AT THE INDUSTRIAL-COMMERSIAL AREA OF ELEONAS, ATHENS, GREECE
}

\author{
Kaitantzian A. ${ }^{1}$ and Loupasakis C. ${ }^{1}$ \\ ${ }^{1}$ Laboratory of Engineering Geology and Hydrogeology, School of Mining and Metallurgical \\ Engineering, National Technical University of Athens, 9 Heroon Polytechniou St., 157 80, Athens \\ Greece,ankait@metal.ntua.gr, cloupasakis@metal.ntua
}

\begin{abstract}
Land subsidence is a common phenomenon occurring in several regions worldwide. The current work focus on the industrial-commersial area of Eleonas, Athens, where vertical displacements were identified by Persistent Scatterer Interferometry (PSI) analysis. The rate of deformation in the study area according to the PSI results, during the period from May 1992 to December 2000, ranged between -1.5 and $-10 \mathrm{~mm} / \mathrm{yr}$. The evaluation of the geological, geotechnical and hydrogeological conditions of the area combined with the PSI data provided substantial information for the interpretation of the land subsidence phenomenon. Also, the knowledge of the land use distribution and the activities taking place in the area helped the detection of its causal factors.
\end{abstract}

Keywords: Geohazard, Aquifer overexploitation, PSI technique.

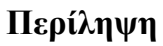

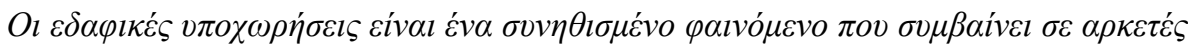

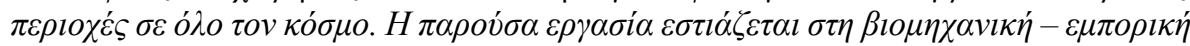

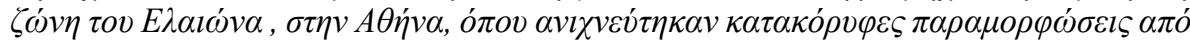

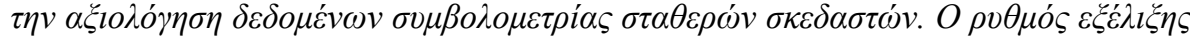

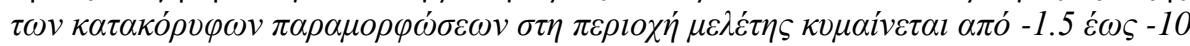

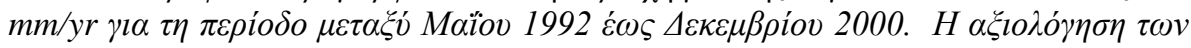

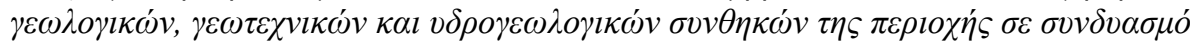

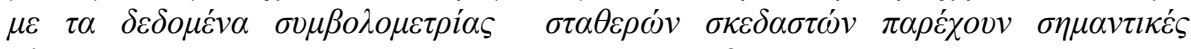

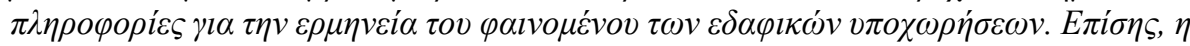

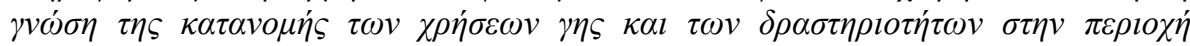

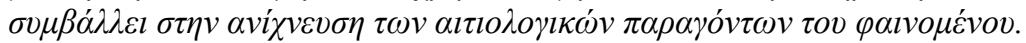

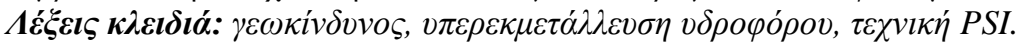

\section{Introduction}

Land subsidence due to the overpumping of aquifers is an important geohazard closely related with the development of urban and industrial areas. The comprehension of the subsidence mechanism can be contributed to prevent or reduce the negative effects of such risk on buildings and infrastructures. Actually, hundreds of cities are affected by land subsidence phenomena worldwide. 
In Greece the well-known areas presenting ground subsidence are the Thessaly Plain (Rozos et al., 2010; Kontogianni et al., 2007; Kaplanides and Fountoulis, 1997), Kalochori village in the east sector of Thessaloniki plain (Costantini et. al., 2016; Raspini et. al., 2014; Loupasakis and Rozos, 2009; Raucoules et al., 2008; Psimoulis et al., 2007; Stiros, 2001; Andronopoulos et al., 1991), the region extending at the west-southwest of the Anargyri opencast coalmine in west Macedonia (Loupasakis et al., 2014; Soulios et al., 2011) and the Messara valley in Crete (Mertikas and Papadaki, 2009).

The current study focuses on the land subsidence phenomena manifesting at the industrialcommersial area of Eleonas. Available land motion mapping data, produced by Persistent Scatterer Interferometry (PSI) analysis, revealed incipient vertical displacements. The main objectives of the current work are to co-evaluate all available data provided by the studies conducted in the area, in order to identify the main causes of the observed ground deformations and to validate the contribution of the remote sensing data on the study of the phenomena.

\section{The study area}

The current study focuses on the industrial-commersial area of Eleonas extending over the municipalities of Athens, Tavros, Ag. Ioannis Rentis and Aegaleo (Fig.1). The Kiffisos River basin has experienced both an increasing urbanization trend and significant population growth in the last few decades.

The study area is occupied by the Athens schist formation overlapped by Neogene and Quaternary sediments. The Athens schist formation is a highly heterogeneous flysch-like formation of Cretaceous age (Marinos et al., 1971). This includes schists, shales, sandstones, marls and limestones of a low-grade metamorphism. The Neogene deposits consist mainly of marls, marly limenstones and sandstones. Their lower sequence consists of conglomerates (pebble size $5-20 \mathrm{~cm}$ ) with sandstones and sandy marls intercalations. The upper sequence consists of lacustrine and terrestrial formations alternations, mainly conglomerates. The dilluvial deposits consist of red sandy loams alternating with breccio-conglomerates of low cohesiveness. The alluvial deposits covering the study area, consist of recent torrential deposits, clays, sand and gravels (Fig.2).

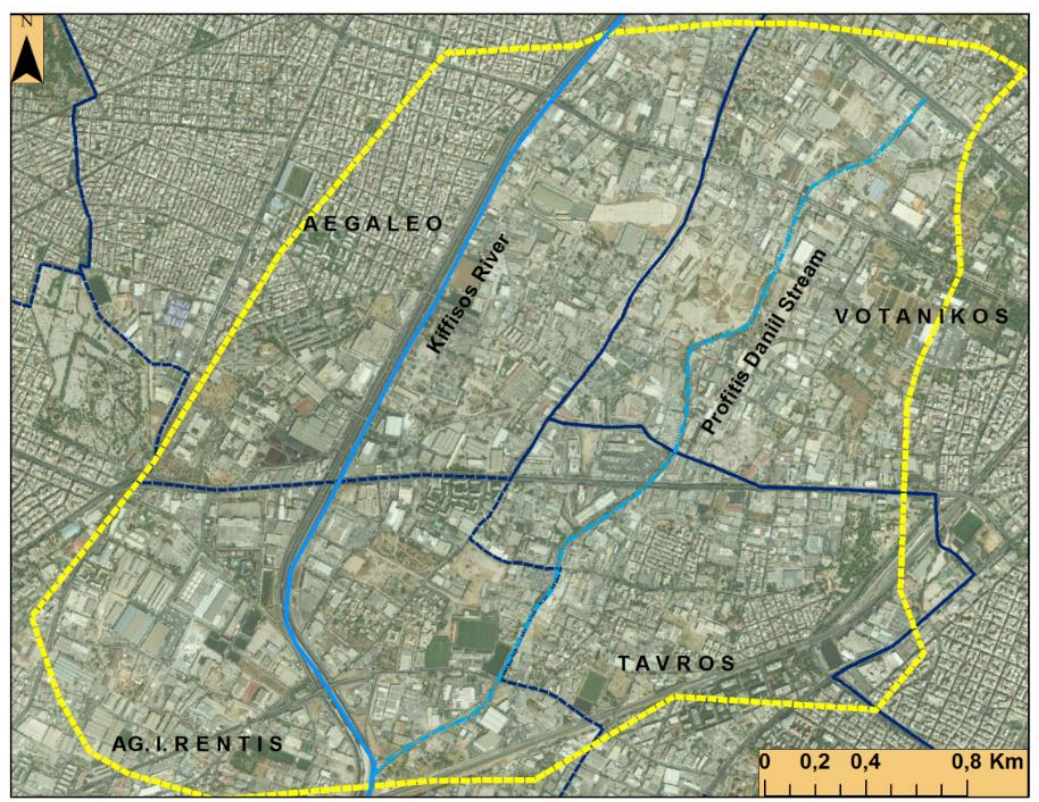

Figure 1 - Location map of the study area. The yellow dotted-line polygon indicates area of interest. 


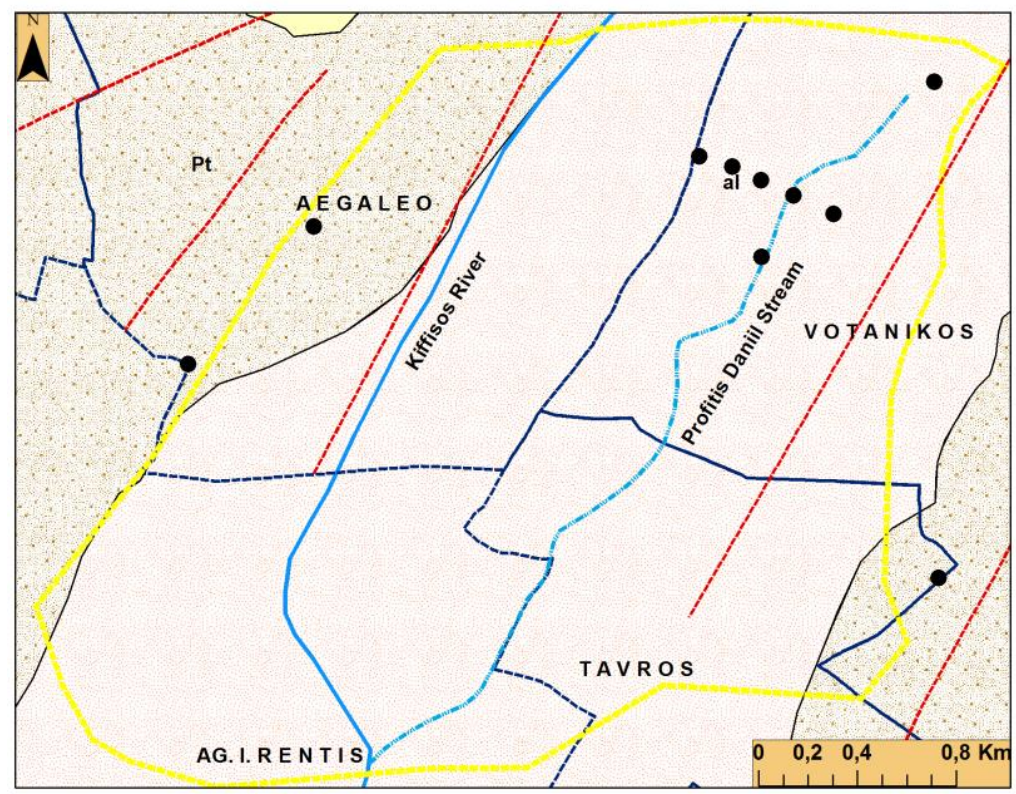

Figure 2 - Geological map of the study area. Black circles indicate geotechnical boreholes drilled. The red dotted lines indicate probably faults.

Considering the aquifers two systems can be distinguished in the abovementioned formations: a) the shallow phreatic aquifers system occupying the alluvial and the dilluvial deposits extending to a maximum depth of $25 \mathrm{~m}$ and b) the semi-confined aquifer occupying the Neogene deposits, characterized by very low hydraulic conductivity.

Thanks to the availability of deep geotechnical boreholes and geophysical surveys a detailed profile down to the depth of $240 \mathrm{~m}$ was established. According to this data the top $20 \mathrm{~m}$ are occupied by finegrained recent deposits. These deposits are composed by brown, sandy, stiff clay of low to medium plasticity (CL). Clayey-silts (CL-ML), clayey-sands (SC), silty sands (SM) and clayey-silty gravels (GM, GM-GC) are also encountered. Underneath the fine-grained recent deposits extend a redbrownish sandy clay (sandy loam) horizon of low to high plasticity (CL, CH) with fine gravels and pisolites intercalated with loose conglomerates. The deeper horizon, reaching down to a maximum depth of $60 \mathrm{~m}$, consists of marls intercalated by sandstones and conglomerates. The marls are whitish-yellow, very stiff to hard, clayey $(\mathrm{CL}, \mathrm{CH})$. Grey, silty marls are also encountered. Although there is not any available geotechnical information for depths over $60 \mathrm{~m}$, the geophysical investigation data showed that the lower horizon consist of Athens schist at least up to the depth of $240 \mathrm{~m}$.

\section{Data and Methodology}

The land subsidence phenomenon in the study area was detected by the PSI technique, a remote sensing technology based on multi-temporal satellite SAR (Synthetic Aperture Radar) imagery. The PSI (Persistent Scatterer Interferometry) techniques are based on the processing of several multitemporal satellite SAR imagery (at least 15-20, or more) of the same target area. The current technique uses long stacks of radar dataset and analyzes the signals backscattered from the observed scene aiming to estimate and remove atmospheric artifacts (Adam et al., 2011). The electromagnetic returns of electromagnetically stable, highly reflective point wise targets (the so-called Permanent Scatterers, (PS) is statistically processed and analyzed to retrieve estimates of the displacements occurred between different acquisitions (Ferretti et al., 2000, 2011). PSs usually correspond to manmade structures (i.e. buildings, roads, bridge, monuments, pylons), as well as natural reflectors, 
such as outcropping rocks. Thanks to this multi-interferometric approach the LOS velocity can be estimated, at each Permanent Scatterer, with unprecedented accuracy, sometimes even better than $0.1 \mathrm{~mm} /$ year. Displacement time series can be retrieved, acquisition by acquisition, with accuracy on single measurements usually ranging from 1 to $3 \mathrm{~mm}$ (Colesanti et al., 2003).

A set of 38 Synthetic Aperture Radar (SAR) images, acquired in 1992-2000 by the European Space Agency (ESA) satellites ERS1 and ERS2, were used for the investigation of land subsidence in the study area.

Besides the space measurements data were also collected geological, hydrogeological and geotechnical data. Available records of piezometric level measurements were also used for the compilation of successive groundwater level contour maps. In order to create the appropriate information platform all available aforementioned data, in the form of maps, were used as the basis for the creation of GIS thematic layers. The data processing involved in their implementation the ArcGIS Desktop v.10 software environment.

\section{Discussion and Conclusions}

An overview of the displacements according to the PSI data is presented in Fig. 3, as measured by the SAR sensor along the satellite's line of sight and expressed in $\mathrm{mm} / \mathrm{y}$. The green dots refer to stable areas. The yellow to red dots represent increasing deformation rates, moving away from the sensor (subsidence). In particular, land subsidence can be mainly identified at the area extending between the riverbeds of Kifisos River and Profitis Daniil Stream with values ranging between -1.5 and $-10 \mathrm{~mm} / \mathrm{yr}$, during the period from May 1992 to December 2000.

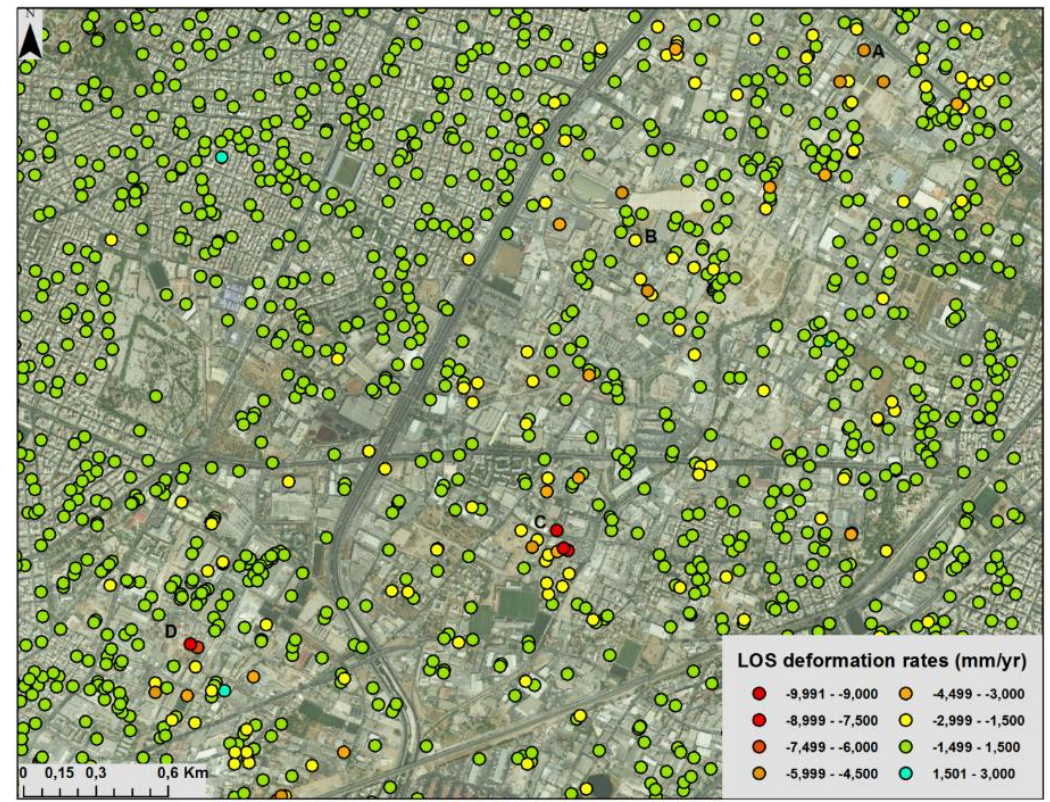

Figure 3 - The Line of Sight - LOS deformation rates in the study area.

Displacements time series available for each PS target are ideally suited for monitoring temporal evolution of displacement for the investigated period of time. Characteristic graphs referring to four Permanent Scatterers affected by ground motion, are reported in Fig.4.

The major part of industrial activity of Athens from the 50s until the 90s has been accommodated in the study area (Fig.5). Many of those industries are food and drink industries, while others are textile - fabric dyeing, chemical and skin processing industries. 


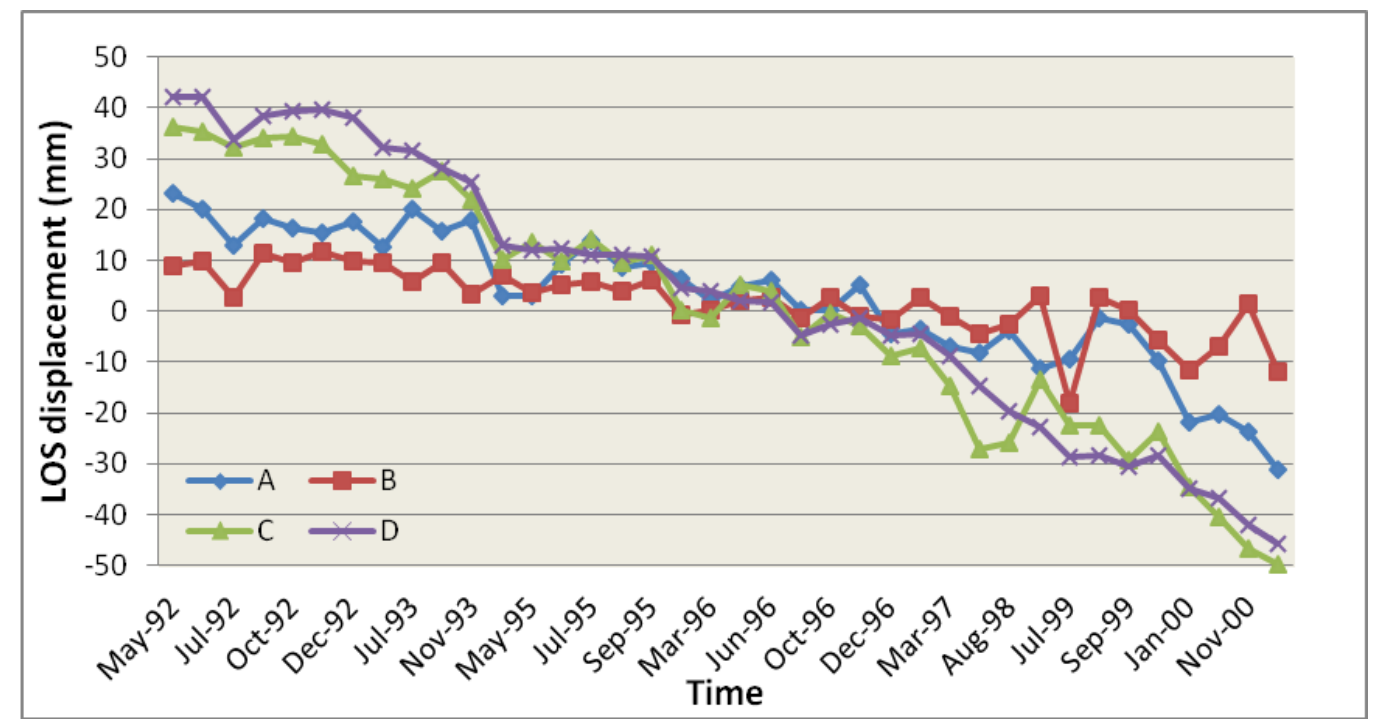

Figure 4 - LOS displacement time series of PS A, B, C and D.

Since the late 90s the activity gradually, but not entirely, changed from industrial to logistics. All afore mentioned activities are high demanding from the water supply point of view. Those needs have been diachronically covered mainly by water exploiting wells. At this point it should be noted that the deformations are entirely limited inside the industrial area.

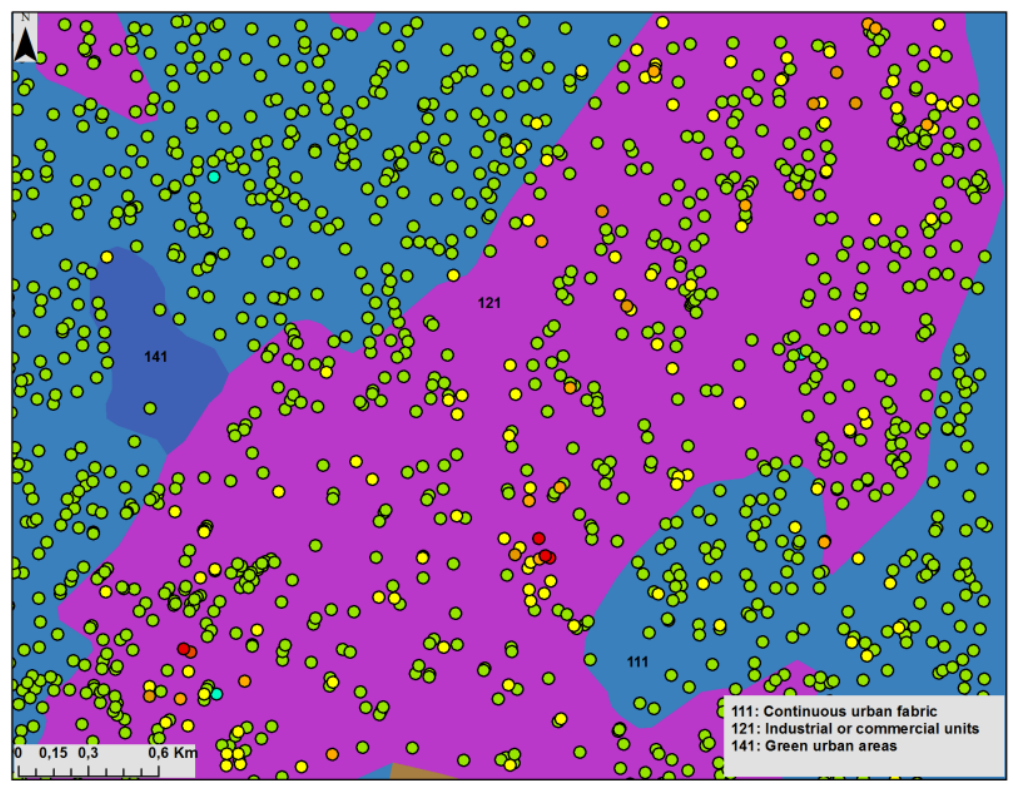

Figure 5 - Land use distribution in the study area (source: Corine, 2000).

At the isopiezometric curves map (Fig.6) referring to the conditions of the shallow phreatic aquifers in March 1997, is presented that the higher ground deformation values occur within the limits of the wider depression cone covering the Eleonas industrial area. In particular the rapid drawdown of the piezometric surface as well as negative ground water level values occurring at the $\mathrm{S}$ to $\mathrm{SE}$ (morphologically lower) part of the study area verify the overexploitation of the aquifers. 


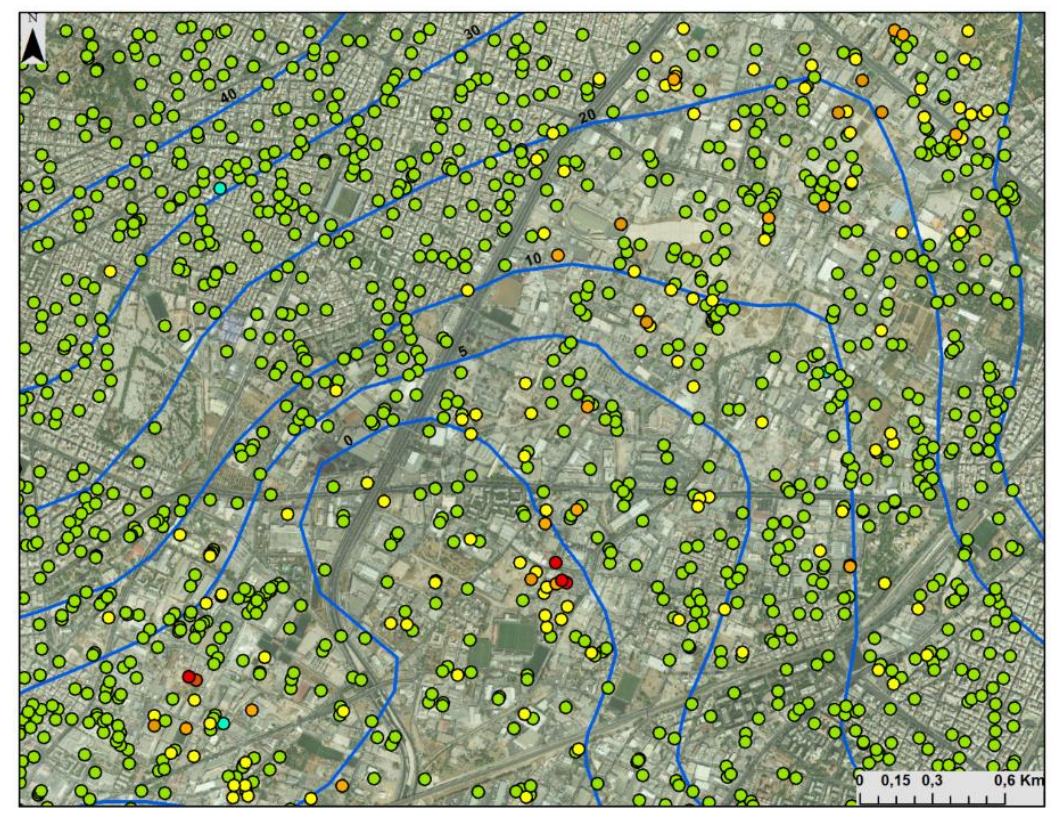

Figure 6 - Isopiezometric map March 1997 (Koumantakis, 1997).

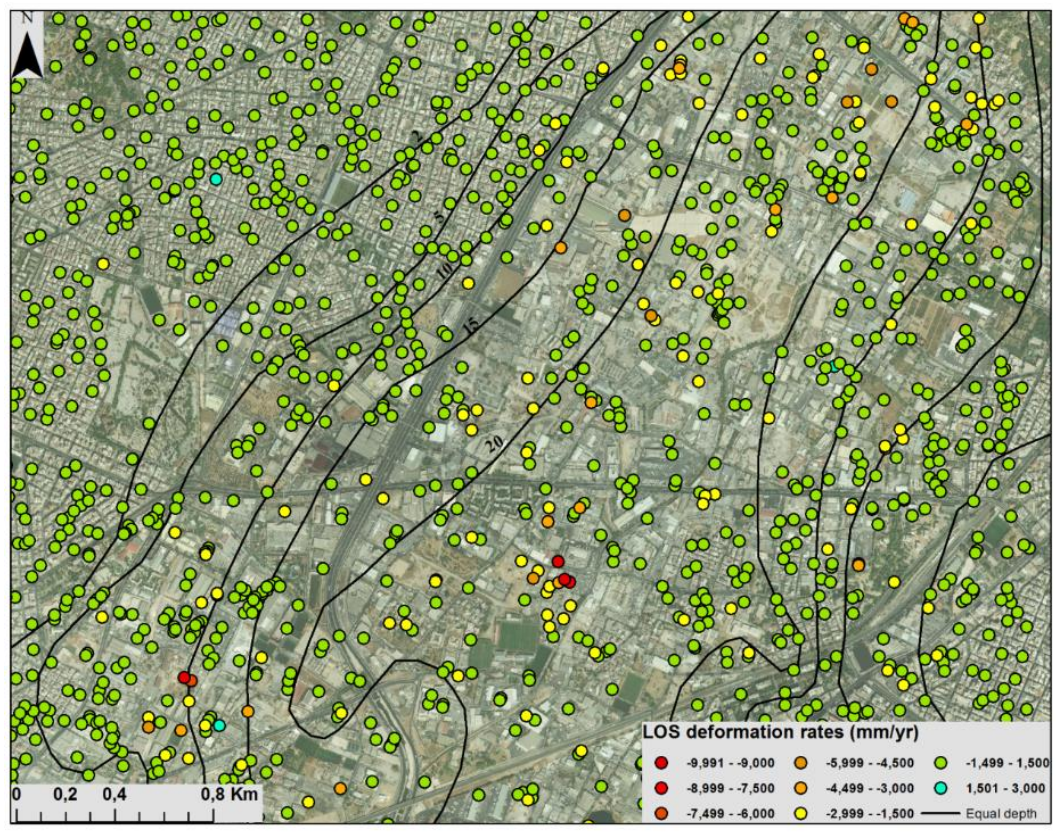

Figure 7 - Equal depth curves of the bedrock basement from Koukis and Sabatakakis, 2000.

A comparison between the equal depth curves of the bedrock Athenian schist formations and the distribution of the vertical displacements indicates that the greater subsidence values have been observed in the area where the thickness of the deposits exceeds over the depth of $20 \mathrm{~m}$ (Fig.7). Obviously, the thickness of the fine-grained deposits contributes to the higher ground deformation. According to the laboratory data the compression index $(\mathrm{Cc})$ of the fine grained layers range from 0.080 to 0.213 , indicating their compressibility potential. 
Concluding from the primary examination of all the data, it appears that the occurring land subsidence phenomena could be attributed primarily to the overexploitation of groundwater reservoir resulting to the compaction fine-grain recent deposits. Furthermore, the natural compaction of the fine grained alluvial deposits cannot be entirely excluded.

Further study of the phenomena can be of significant interest considering the plans for the future development of the area.

\section{Acknowledgments}

The Terrafirma Extension project has funded the SAR imagery processing. The Terrafirma project is one of the many services supported by the Global Monitoring for Environment and Security (GMES) Service Element Programme, promoted and financed by ESA. The authors gratefully acknowledge the German Aerospace Centre (DLR) for having processed the SAR data.

\section{References}

Adam, N., Rodriguez Gonzalez, F., Parizzi, A. and Liebhart, W., 2011. Wide area persistent scatterer Interferometry, Proc. of IGARSS, Vancouver, Canada.

Andronopoulos, V., Rozos, D. and Hatzinakos, I., 1991. Subsidence phenomena in the industrial area of Thessaloniki, Greece. In: Johnson, A., ed., Land Subsidence, 200, Wallingford, Oxfordshire, IAHS Publishers, 59-69.

Colesanti, C., Ferretti, A., Prati, C. and Rocca, F., 2003. Monitoring landslides and tectonic motion with the Permanent Scatterers technique, Eng. Geol., 68, 3-14.

CORINE land cover 2000 project, Commission of the European Communities.

Costantini, F., Mouratidis, A., Schiavon, G. and Sarti, F., 2016. Advanced InSAR techniques for deformation studies and for simulating the PS-assisted calibration procedure of Sentinel-1 data: Case study from Thessaloniki (Greece), based on the Envisat / ASAR archive, Int. Journal of Remote Sensing, 37, 729-744, doi: 10.1080/01431161.2015.1134846.

Ferretti, A., Prati, C. and Rocca, F., 2000. Nonlinear subsidence rate estimation using Permanent Scatterers in differential SAR interferometry, IEEE T. Geosci. Remote, 38, 2202-2212.

Ferretti, A., Fumagalli, A., Novali, F., Prati, C., Rocca, F. and Rucci, A., 2011. A new algorithm for processing interferometric data-stacks, SqueeSAR ${ }^{\mathrm{TM}}$, IEEE T. Geosci. Remote, 99, 1-11.

Kaplanides, A. and Fountoulis, D., 1997. Subsidence phenomena and ground fissures in Larissa, Karla basin, Greece: their results in urban and rural environment. In: Marinos, P., Koukis, G., Tsiambaos, G. and Sambatakakis, G., eds., Eng. Geol. Environ., 729-735.

Kontogianni, V., Pytharouli, S. and Stiros, S., 2007. Ground subsidence, Quaternary faults and vulnerability of utilities and transportation networks in Thessaly, Greece, Environ. Geol., 52, 1085-1095.

Koukis, G. and Sabatakakis, N., 2000. Engineering geological environment of Athens, Greece, Bull. Eng. Geol. Environ, 59, 127-135.

Koumantakis, I., 1997. Research of hydrogeological conditions and of the operating procedures of the ground water in the basin of Attica, Main Issue, ( $\mathrm{A}^{\prime}$ and $\mathrm{B}^{\prime}$ Phase), research program in the years 1996 and 1997 performed by the research team of the Section of Geological Sciences in cooperation with the Organization of Planning and Environmental Protection of Athens.

Loupasakis, C., Agelitsa, B., Rozos, D. and Spanou, N., 2014. Mining geohazards-land subsidence caused by the dewatering of opencast coal mines: The case study of the Amyntaio coal mine, Florina, Greece, Natural Hazards, Springer, 70, 675-691, doi: 10.1007/s11069-013-0837-1.

Loupasakis, C. and Rozos, D., 2009. Land subsidence induced by water pumping in Kalochori village (north Greece) - simulation of the phenomenon by means of the finite element method, Q. J. Eng. Geol. Hydrog., 42, 369-382.

Marinos, G., Katsikatsos, G., Georgiadou-Dikeoulia, E. and Mirkou, R., 1971. The Athens' schist formation. I. Stratigraphy and structure (in Greek), Ann. Geol. Pays Hell., 22, 183-216. 
Mertikas, S.P. and Papadaki, E.S., 2009. Radar Intererferometry for Monitoring Land Subsidence due to over-pumping Ground Water in Crete, Greece, Proc. of the Fringe Workshop, Italy, 30 November- 4 December.

Psimoulis, P., Ghilardi, M., Fouache, E. and Stiros, S., 2007. Subsidence and evolution of the Thessaloniki plain, Greece, based on historical levelling and GPS data, Eng. Geol., 90, 55-70.

Raspini, F., Loupasakis, C., Rozos, D. and Moretti, S., 2013. Advanced interpretation of land subsidence by validating multi-interferometric SAR data: the case study of the Anthemountas basin (northern Greece), Nat. Hazards Earth Syst. Sci. Discuss., 1, 1213-1256.

Raucoules, D., Parcharidis, I., Feurer, D., Novalli, F., Ferretti, A., Carnec, C., Lagios, E., Sakkas, V., Le Mouelic, S., Cooksley, G. and Hosford, S., 2008. Ground deformation detection of the greater area of Thessaloniki (Northern Greece) using radar interferometry techniques, Nat. Hazards Earth Syst. Sci., 8, 779-788, doi: 10.5194/nhess-8-779(08).

Rozos, D., Sideri, D., Loupasakis, C. and Apostolidis, E., 2010. Land subsidence due to excessive groundwater withdrawal, a case study from Stavros-Farsala site, west Thessaly Greece, Proc. of the 12th International Congress, Patras, Bull. Geol. Soc. Greece, 4, 1850-1857.

Soulios, G., Tsapanos, T., Voudouris, K., Kaklis, T., Mattas, C. and Sotiriadis, M., 2011. Ruptures on surface and buildings due to land subsidence in Anargyri village (Florina Prefecture, Macedonia), Environ. Earth Sci., 5, 505-512.

Stiros, S.C., 2001. Subsidence of the Thessaloniki (northern Greece) coastal plain, 1960-1999, Eng. Geol., 61, 243-256. 